\title{
A study of the phytotoxic effects of the aerial parts of Senecio westermanii Dusén (Asteraceae) on Lactuca sativa L. and Allium cepa L. seeds
}

\author{
Francis José Zortéa Merino ${ }^{1 *}$, Daniele Felipe Ribas ${ }^{1}$, Cristiane Bezerra da Silva ${ }^{1}$, \\ Ana Flávia Schvabe Duarte ${ }^{1}$, Cristiane da Silva Paula ${ }^{1}$, Maislian de Oliveira ${ }^{1}$, \\ Josiane de Fátima Gaspari Dias' ${ }^{1}$, Marilis Dallarmi Miguel ${ }^{1}$, Obdulio Gomes Miguel ${ }^{1}$
}

${ }^{1}$ Federal University of Paraná, Pharmacy Department, Curitiba, Paraná, Brazil

\begin{abstract}
The objective of this study was to evaluate the effects of the ethanolic crude extracts and fractions of the species Senecio westermanii Dusén on Lactuca sativa L. (lettuce) and Allium cepa L. (onion) seeds. We assessed the germination, growth, root respiration and photosynthesis of the target species in Petri dishes $\left(9.0 \mathrm{~cm}\right.$ diameter) containing filter paper $\mathrm{n}^{\circ} 6$. The study was conducted using 50 seeds per plate and held in 4 replicates per concentration of each sample. In the germination there was an inhibitory effect of fractions hexane (FH) and chloroform $(\mathrm{FCl})$ at concentrations of 500 and $1000 \mu \mathrm{g} / \mathrm{mL}$. There was a reduction in the radicle growth of lettuce by 14 to $24 \%$ and a reduction of hypocotilum by 14 to $28 \%$. As for the radicle of the onion was up $74 \%$ reduction to the $\mathrm{FCl}$ and the coleoptile was 24 and $45 \%$ reduction for $\mathrm{FH}$ and $\mathrm{FCl}$, respectively. Inhibitory effects in the root respiration of lettuce were detected in all the samples analyzed, with results ranging from 16 to $83 \%$. For the seeds of $A$. cepa, there was an encouragement for the $\mathrm{FCl}$ and ethyl acetate fractions (FAE), with results ranging from 94 to $142 \%$ and 76 to $150 \%$, respectively. With regard to the photosynthesis of $L$. sativa, there was no significant difference between the control, and as for the A. серa, there was a strain in inhibition concentrations of 250 and $500 \mu \mathrm{g} / \mathrm{mL}$, which ranged from 27 to $68 \%$. The samples of $S$. westermanii caused changes in the target species and thus can be used as a natural herbicide.
\end{abstract}

Keywords: Senecio westermanii/extract/effects. Lactuca sativa. Allium cepa. Allelochemicals. Allelopathy.

\section{INTRODUCTION}

Allelopathy plays a key role in the detection of bioactive compounds of commercial importance. Several studies indicate that the allelochemicals of plant products are agrochemicals ideal for creating biological changes (El-Amier, Abdullah, 2014).

The presence of weeds among crops raises the cost of production for farmers, especially for intensive agriculture, as it induces changes in the population of these plants, changing the predominant species that best fits the middle. The interference of these plants in cultures of commercial interest occurs by the allelopathic effect and competition for water, light, $\mathrm{CO}_{2}$ and nutrients, causing

\footnotetext{
*Correspondence: F. J. Z. Merino. Universidade Federal do Paraná, Departamento de Farmácia, 80210-170 - Pref. Lothário Meissner Road, 632, Jardim Botânico, Curitiba, Paraná, Brazil. E-mail: secocio@yahoo.com.br.
}

a qualitative and quantitative reduction in production (Ferreira, Souza, Faria, 2007).

The negative effects of allelopathy on germination lead to the non-uniformity of culture, as the allelochemicals can cause oxidative stress, forming reactive oxygen species and causing damage in the physiological processes and early development of seedlings (Silva, 2012).

The allelopathic effects and mechanism of action of allelochemicals are fundamental to understanding the interaction between plants. The production of allelopathic substances and the natural chemistry differ between plant species, as well as with regard to the sensitivity to allelochemicals of other plants. These differences may affect the species' specifics and quantitative composition of weed communities (Cruz-Silva et al., 2015).

The main release of these components are leaching, volatilization and decomposition, which can change the membrane permeability, absorption of nutrients, growth, 
photosynthesis, enzymatic activity, and respiration. When these substances are released into the environment, they are capable of influencing the metabolism of the surrounding species (Silva, 2012).

The allelopathic compounds produced by higher plants are synthesized by the acetic acid and shikimic routes, and among the most active substances cyanogenic glycosides, phenolic, quinones, lactones, volatile organic acids and terpenes are present (Możdżeń, Repka, 2014).

The production of allelochemicals is influenced by factors such as temperature, humidity and soil type, and your summary is an evolutionary process as part of the defense system. These substances are present in the leaves, bark, roots, flowers, stems, fruits and seeds of various plant species (Borella, Pastorini, 2009).

Francescato et al. (2007) comment that one of the main reasons for the use of the genus Senecio L. in folk medicine is the different classes of secondary metabolites identified. In this genus, some species were able to change the development of other plant species through bioassays.

According to Ahmed, Wardle (1994), the species $S$. jacobaea $L$. was able to change the development of Lolium perenne L. (perennial ryegrass), Trifolium repens $L$. (white clover), $T$. pratense $L$. (red clover), $T$. subterraneum L. (subterranean clover) and Medicago sativa L. (lucerne). The species $S$. brasiliensis (Spreng) altered the germination and development of Lactuca sativa L. (lettuce), Zea mays L. (corn) and Glycine max (L.) Merr (soy) less (Cruz-Silva, Satorum, Bini, 2009). In addition to these species, $S$. vulgaris presented allelopathic effects against Sorghum bicolor (sorghum) (Schutt et al., 1975).

Merino et al. (2015) detected the presence of alkaloids, flavonoids, iridoides, steroids, saponinic glycosides and amino group in $S$. westermanii, in a study aimed at evaluating the germination velocity index, growth, root respiration and photosynthesis of Lactuca sativa L. (lettuce) and Allium cepa L. (onions) in direct contact with crude ethanolic extract and fractions hexane, chloroform, ethyl acetate and hydroalcoholic remaining aerial parts of $S$. westermanii Dusén.

\section{MATERIAL AND METHODS}

\section{Plant material}

Senecio westermanii Dusén was collected at Quatro Barras in Paraná, Brazil, at coordinates $25^{\circ} 18^{\prime} 27^{\prime \prime} \mathrm{S}$ and 48 56'37' W. The exsicata was deposited (MBM 379066) and identified in the Botanical Museum Municipal of Curitiba, Paraná. The project was regularized in accordance with resolution no. 35, of 27 April 2011, by the Ministry of environment, which provides for regulating access to genetic heritage activities.

\section{Obtaining the crude extract and fractions}

$6300 \mathrm{~g}$ were dried plant at room temperature $\left(25^{\circ} \mathrm{C}\right)$ and crushed in knife and hammer mill. From this mass of crude extract obtained in ethanolic Soxhlet apparatus modified under the registration PI 0601703-7 and concentrated on the $150 \mathrm{rpm}$ rotary evaporator at $65^{\circ} \mathrm{C}$. Then the crude extract (CE) was partitioned by liquid/ liquid extraction with solvents of increasing polarity, obtaining fractions of hexane (HF), chloroform (CLF), ethyl acetate (EAF) and remaining (RHF) (Carvalho et al., 2009).

\section{Study of allelopathic activity}

$5 \mathrm{~mL}$ of crude extract and fractions $(250 \mu \mathrm{g} / \mathrm{mL}$, $500 \mu \mathrm{g} / \mathrm{mL}$ and $1,000 \mu \mathrm{g} / \mathrm{mL}$ ) were added in Petri dishes $(\mathrm{d}: 9.0 \mathrm{~cm})$ containing filter paper Whatman $\left(\mathrm{n}^{\circ} .1 .0\right)$. Then, they were placed randomly on 50 diasporas of Lactuca sativa and Allium cepa. The plates containing the diasporas were placed in the germination chamber (BOD) with internal light conditions, constant $160 \mathrm{~W}$, relative humidity $( \pm 80 \%)$ and temperature of $25^{\circ} \mathrm{C}$. All testing was conducted in four replications, including distilled water control (Brasil, 2009).

\section{Germination}

The readings were taken at $12-12$ hours for seven days, always at the same time, considering the germinated the seeds with visible radicle protrusion through the integument. It has been estimated the germination velocity index (GVI) noting daily the number of germinated seeds. In the end, the number of germinated seeds were added by day, by dividing by the number of days from seeding according to the formula: $\mathrm{GVI}=(\mathrm{G} 1 / \mathrm{N} 1)+(\mathrm{G} 2 / \mathrm{N} 2)+\ldots$ $+(\mathrm{Gn} / \mathrm{Nn})$, where "G" is the number of germinated seeds and " $\mathrm{N}$ " is the number of days from sowing to the $1 \mathrm{st}, 2 \mathrm{nd}$, ..., umpteenth evaluation (Laboriau, 1983).

\section{Growth}

For the bioassay, the growth methodology described by Barnes et al. (1987) and Macias, Castellano, Molinillo (2000) was followed. After three days of root protrusion, the radicle elongation and hypocotilum (Lactuca sativa)/ coleoptile (Allium cepa), with ten seedlings per plate, were measured with graph paper. 


\section{Respiration of roots}

The test was performed according to Steponkus, Lanphear (1967). 10 roots were cut and transferred to test tubes containing $5 \mathrm{~mL}$ of triphenyl tetrazolium hydrochloride (TTC) $0.6 \%(\mathrm{p} / \mathrm{v})$ and $1 \mathrm{~mL}$ of buffered sodium phosphate (mono-and dibasic) $0.05 \mathrm{M}(\mathrm{pH}$ 7.0). Then, the tubes were left at room temperature for 2 hours. After this period, the tubes were transferred to an oven at $40{ }^{\circ} \mathrm{C}$ for 15 hours. The solution was drained and rinsed with distilled water and added with $7 \mathrm{~mL}$ of $95 \%$ ethanol $(\mathrm{v} / \mathrm{v})$ and packed in a water bath $\left( \pm 100{ }^{\circ} \mathrm{C}\right)$ for 15 mins. After cooling, $10 \mathrm{~mL}$ of ethanol $95 \%$ (v/v) was added, and the reading was performed in the $530 \mathrm{~nm}$ spectrophotometer.

\section{Photosynthesis}

10 primary leaves - whole and sectioned-were placed in test tubes containing $5.0 \mathrm{~mL}$ of DMSO, and the tubes were wrapped in aluminum foil and kept at room temperature $\left(25^{\circ} \mathrm{C}\right)$ for 24 hours. At the end of the period, the readings of chlorophyll a $(645 \mathrm{~nm})$ and $b$ $(663 \mathrm{~nm})$ were performed with a spectrophotometer. The total chlorophyll content was calculated according to the equation of Arnon (1949) and Lichtenthaler (1987):

$$
\text { Chlorophyll total: } 20.2 \times \mathrm{Abs} A+8.02 \times \mathrm{AbsB}
$$

where: $\mathrm{AbsA}=$ absorbance of the chlorophyll a; $\mathrm{AbsB}=$ absorbance of the chlorophyll $b$.

\section{Statistical analysis}

From the results, the statistical analysis was performed by the Scott-Knott test $(p<0.05)$, using the software Sisvar 5.4 (Build 80). The graphs were compiled using GraphPad Prism 6.01 software.

\section{RESULTS AND DISCUSSION}

According to the results presented with the extract and fractions of $S$. westermanii, the allelopathic pattern in L. sativa and A. cepa were different. L. sativa had an inhibition in the GVI treated with fractions HF and CLF (500 and $1000 \mu \mathrm{g} / \mathrm{mL}$ ), while the GVI of A. cepa was unchanged by the samples (Figure 1).

The species $L$. sativa (lettuce) in the class of dicots

A

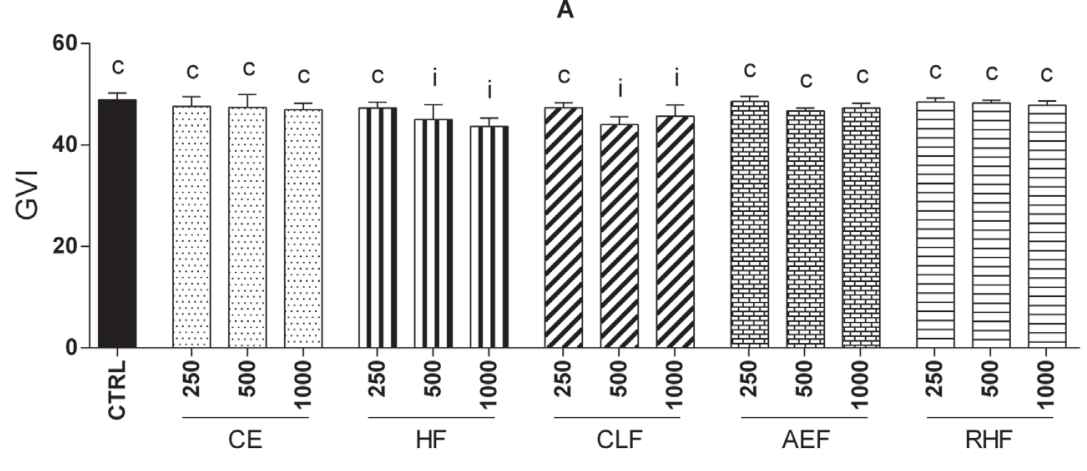

B

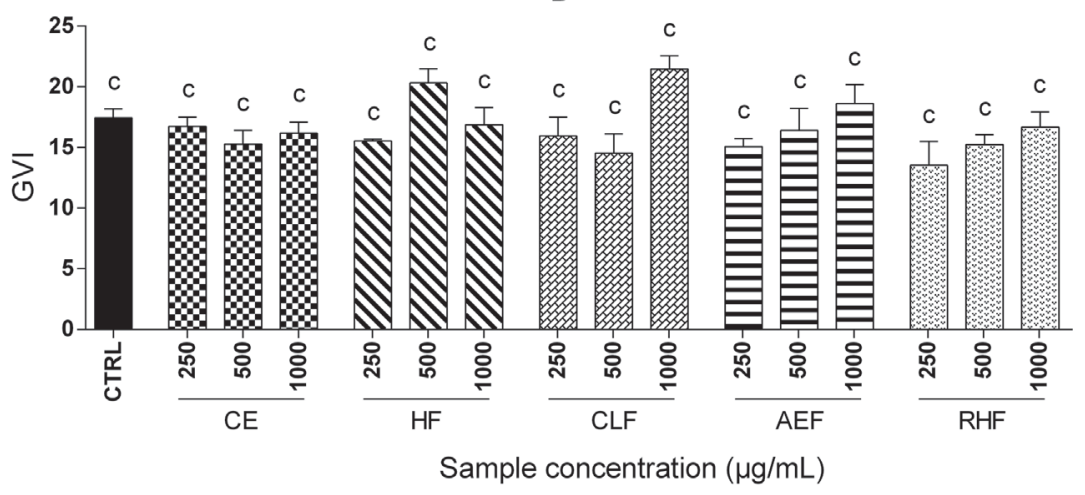

FIGURE 1 - Germination velocity index (GVI) of L. sativa (A) and A. cepa (B). Treatment means differ significantly (p<0.05) when compared to control means inhibiting or ${ }^{\mathrm{e}}$ stimulating germination velocity by Scott-Knott test. Treatment means do not differ significantly from ${ }^{\mathrm{c}}$ control means. 
is widely used in allelopathic tests for being sensitive to various plant extracts and diminishing germination and changing the GVI (Wandscheer, Pastorini, 2008). While the target species $A$. серa (onion) belongs to monocotyledons, it is also used in studies of allelopathic interference with extracts of plant species (Abdelgaleil, Hashinaga, 2007).

Several species of plants representing different genus feature allelopathic activity on germination of $L$. sativa as Solanum megalochiton Mart (Krause et al., 2016), Aristolochia esperanzae O. Kuntze (Gatti, Perez, Lima, 2004), Bidens pilosa and B. alba (Lima et al., 2011).

However, for the seeds of $A$. cepa, some studies have shown that this species of monocotyledon was not influenced by other species in germination. A study by Oliveira et al. (2012) with different extracts of Solanum lycocarpum, where different target species were studied, showed that only the seeds of $A$. cepa were indifferent in germination. The same was observed in Parvez et al. (2004) when studying the allelopathic effect with seeds and bark of Tamarindus indica L.

The change in germination index demonstrates that there occur changes in metabolic reactions that are part of the germination. But with the rise of that index, there is possibly a loss of sync in these reactions affecting germination (Maraschin-Silva, Aqüila, 2006).

According to Dodd, Donovan (2009), the germination and growth of seeds are critical stages and subject to high rates of failure, as the seeds are more susceptible and less tolerant to various environmental factors.

The allelochemicals inhibit and change the patterns of growth or development of plants, possessing a selective form of action. Plants act by modulating the action of these chemical compound forms, becoming the complex knowledge of attack of the allelochemicals (Gatti, Perez, Lima, 2004). The allelopathic action among species involves a complex chemical interaction between plants because of the low concentrations of allelochemicals in the environment; this demonstrates that the allelopathic action is due to the effect of various substances that act together, causing the allelopathic effect (Maraschin-Silva, Aqüila, 2006).

Belinelo et al. (2008) commented that the mechanism by which the allelochemicals act is related to the modification of physiological processes and biochemical processes. Souza, Velini, Maiomoni-Rodella (2003) pointed out that a series of compounds can affect the physiological activity of target plants, and there is a respiration that can be modified for aromatics, aldehydes, phenols, flavonoids and coumarins. In addition to these compounds, they may also have crystals, such as the raphids of calcium oxalate, and natural polymers, such as tannins, lignins and resins.
As the allelopathic effect is mediated by different classes of secondary metabolites, it becomes difficult to identify which of the groups comes from the occurred effect.

The allelopathic activity, as a result of the test, can be linked to the synergistic effect of various allelochemicals found in the species. In addition, the secondary compounds produced by plants are mostly applied in other species, modifying the development and effect of the organisms affected and reducing their populations (Moreira, Souza, Terrones, 2008).

In the studies with species of the genus Senecio, it was observed that secondary compounds were responsible for the change in the germination pattern of the target species. The $\beta$-caryophyllene compound isolated from $S$. salignus inhibited the germination of Physalis ixocarpa at the concentration of $150 \mu \mathrm{g} / \mathrm{mL}$, but the caryophyllene oxide did not affect germination (Sánchez-Muñoz et $a l ., 2012)$. The hydroxylated eremophilanolide $(1 \alpha, 6 \beta$, $10 \beta$-trihydroxy- $8 \alpha$-methoxyeremophil-7(11)-en-12,8 $\beta$ olide) isolated from $S$. candidans and $S$. magellanicus reduced the germination of L. sativa by $25 \%$ (Reina et al., 2012).

Burgueño-Tapia et al. (2007) evaluated six cacalolides and six eremophilanolides in L. sativa seeds, a cacalolide isolated from $S$. madagascariensis (14-isovaleryloxy-1,2-dehydrocacalol methyl ether (1)), two cacalolides from $S$. barba-johannis (13-hydroxy14-oxocacalohastine (2) and 13-acetyloxy-14oxocacalohastine (3)) and three eremophilanolides of S. toluccanus (6-hydroxyeuryopsin (4), 1(10)-epoxy6-hydroxyeuryopsin (5) and toluccanolide A (6)), in addition, with three cacalolides derivatives (methyl ether (7), cacalol acetate (8) and 1-acetyloxy-2-methyloxy1,2,3,4-tetradehydrocacalol acetate (9)) and three eremophilanolides derivatives (6-acetyloxyeuryopsin (10), 6-acetyloxy-1(10)-epoxyeuryopsin (11) and toluccanolide A acetate (12)). The authors observed that compounds 2-6 and 12 inhibited germination by $>50 \%$ within 24 hours.

In the root growth, both species have undergone changes in the pattern of growth with the inhibition of the radicle and hypocotilum (lettuce)/coleoptile (onion). For $L$. sativa, the radicle had a growth delay in all concentrations of CE, CLF and the largest concentrations of the other fractions. The results show that there has been a reduction in the development by 14 to $24 \%$ in the size of the radicle. The greatest influence occurs in hypocotilum because all the fractions and the $\mathrm{CE}$ delayed growth, and there has been a reduction from 14 to $28 \%$. For the radicle of $A$. сеpa, there was a similar inhibition pattern, but with a reduction in all concentrations of CE, HF and RHF, there was a reduction in the growth by up to $74 \%$ on CLF. As for coleoptile, there was 
a reduction in the $\mathrm{HF}(250 \mu \mathrm{g} / \mathrm{mL})$ and $\mathrm{CLF}(250 \mu \mathrm{g} / \mathrm{mL})$, with a reduction of 24 to $45 \%$, respectively (Figure 2 ). This shows that the species can change the growth of seedlings tested in early development.
The allelopathic effect of Sorghum bicolor on the growth of L. sativa and Zea mays L. plants that belong to different classes, different results. And for the seeds of lettuce, a reduction in cell elongation of the root was

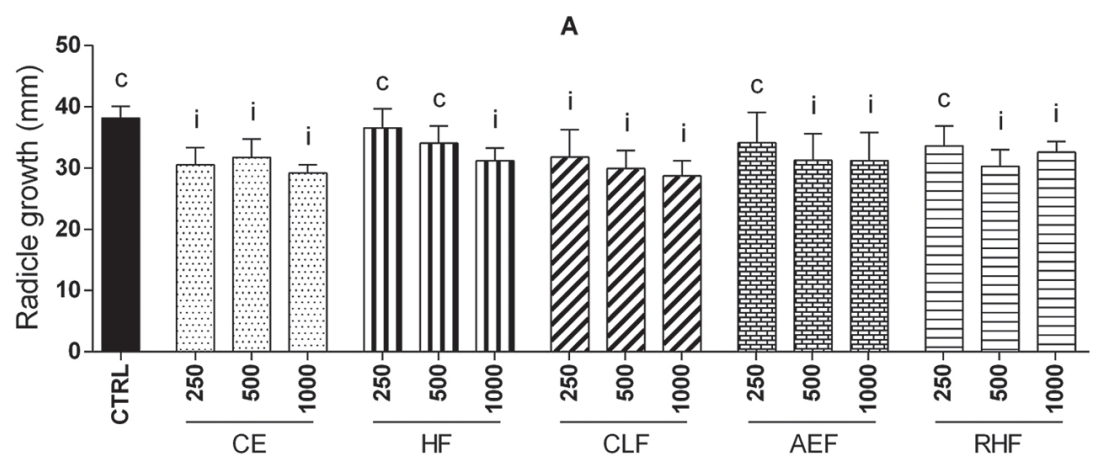

B

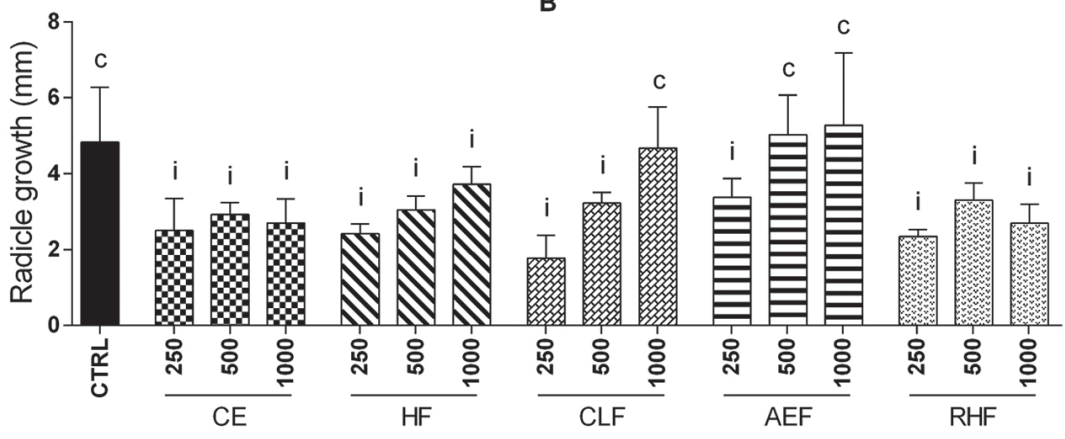

C
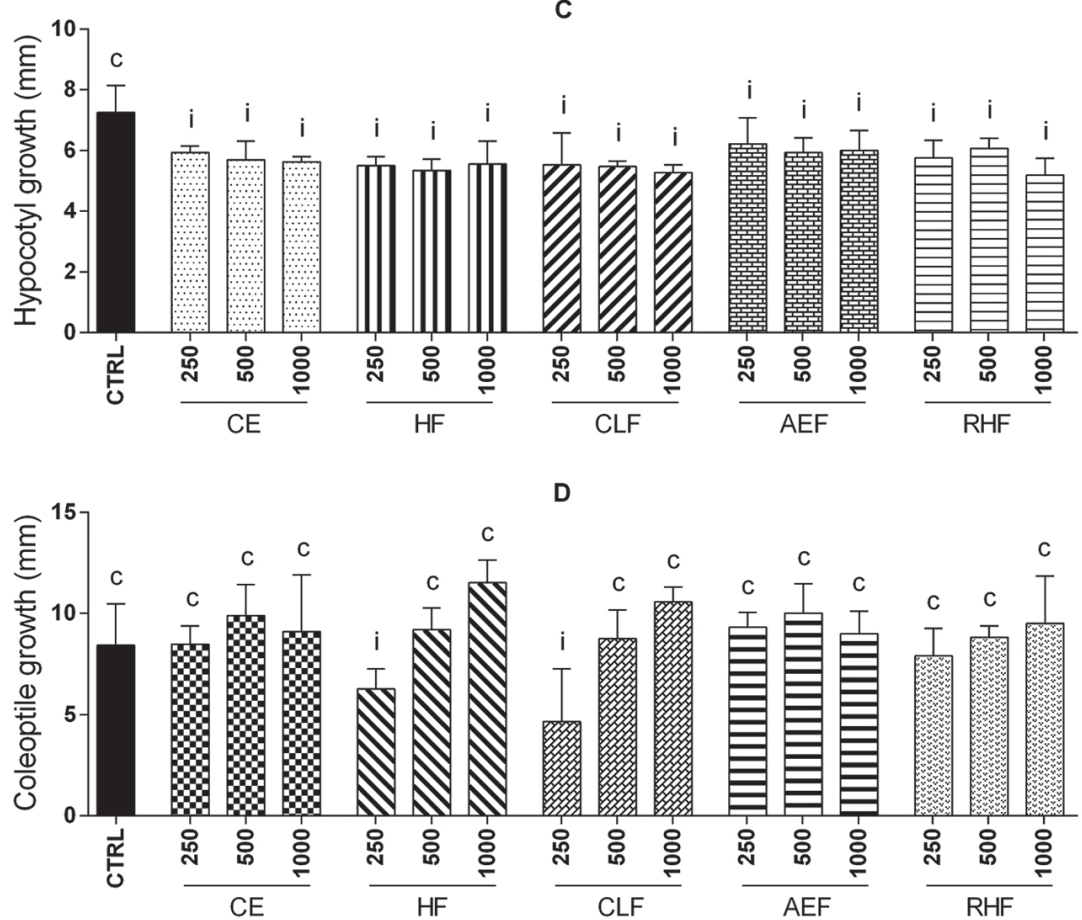

FIGURE 2 - Root growth of L. sativa (A and C) and A. cepa (B and D). Treatment means differ significantly ( $<<0.05)$ when compared to control means inhibiting or ${ }^{\mathrm{e}}$ stimulating root growth by Scott-Knott test. Treatment means do not differ significantly from ${ }^{c}$ control means. 
observed, while for corn there was no significant difference (Netzly et al., 1988). Otherwise, the result demonstrated for the seeds of A. cepa, which is also monocots, with the samples of $S$. westermanii was that they were able to change the root development. This demonstrates that the action and the effect sense for species of the same class can present different answers.

The root growth and elongation of the aerial parts are due to the formation of the cambium and xylem, but they depend on the distribution of nutrients for the seedling. In addition, the development occurs through cell division (Hoffmann et al., 2007).

Comparing the effect on the aerial parts with the roots of plants, phytotoxic effects are more pronounced in the root region due to the direct contact of the roots with the fractions, increasing the likelihood of influence of toxins in this region (Cândido et al., 2010).

The bioassays of radicle elongation have been shown to be more sensitive to the allelopathic effects than the germination of seeds (Souza Filho, Guilhon, Santos, 2010). In addition, allelopathic studies have demonstrated inhibitory effects, mainly in primary root (MaraschinSilva, Aqüila, 2006). The results also demonstrate that when comparing the results of germination and root growth for L. sativa and A. cepa, it is observed that the inhibitory effect was most prominent in roots compared to germination.

Several studies prove the interference of secondary compounds of the genus Senecio on the root growth of the target species. The $\beta$-caryophyllene compound isolated from $S$. salignus inhibited the root growth in P. ixocarpa by 42 to $53 \%$ at concentrations of 50 to $150 \mu \mathrm{g} / \mathrm{mL}$, respectively, and inhibited the Echinochloa crus-galli root length by $30 \%$ in a concentration of $150 \mu \mathrm{g} / \mathrm{mL}$. Moreover, caryophyllene oxide inhibited the elongation of E. crusgalli root by $23 \%$ and $30 \%$ with 100 and $150 \mu \mathrm{g} / \mathrm{mL}$, respectively (Sánchez-Muñoz et al., 2012).

In addition to the $S$. candidans and $S$. magellanicus species, several sesquiterpenes were isolated, and the derivatives of these compounds were obtained, using an eremophilanolide derivative with a carbonyl at carbon 1 and another with a double bond between carbons 1 and 10, which inhibited the elongation of the L. sativa radicle (Reina et al., 2012). The secondary metabolite furanoeremophilane (6 $\beta$-tigloyl9-oxofuranoeremophilane) present in $S$. macrotis, $S$. asperulus (Portero et al., 2012) and S. magellanicus (Reina et al., 2012) were also able to delay the development of L. sativa radicle.

In Burgueño-Tapia et al. (2007), a study involving S. madagascariensis, S. barba-johannis and S. toluccanus species, it was observed that the compounds (1) (3) (5) (7) (8) (9) and (11), previously reported, obtained an inhibition on $L$. sativa radicle $>50 \%$. In addition to these compounds, the silphinene sesquiterpene isolated from $S$. palmensis (Reina et al., 2002) inhibited the root length of Amaranthus hypochondriacus L. (Rivero-Cruz et al., 2000).

Although most compounds delay root growth of the target species, the compounds $6 \beta$-hydroxy- $8 \alpha$ methoxyeremophila-1(10),7(11)-dien-12,8 $\beta$-olide; Tolucanolide A and Tolucanolide C from S. candidans and $S$. magellanicus were able to stimulate the root development of L. sativa (Reina et al., 2012).

With regard to the root respiration of L. sativa, there was inhibition in all the samples analyzed, ranging from 16 to $83 \%$. As for the seeds of A. cepa, there was an encouragement for the fractional CLF and EAF with results that ranged from 94 to $142 \%$ and $150 \%$ to 76 , respectively (Figure 3).

The allelochemicals present in plants are able to stimulate or inhibit cellular respiration, and this can occur according to the compounds present.

The allelochemicals alter the water balance and cellular respiration of plants exposed to plant extracts. The cellular respiration is affected because the secondary metabolites interfere in the steps of this process. A change in breathing may have occurred in the cell membranes, thus changing the functioning of mitochondria and contributing to the reduction of plant growth (Carmo, Borges, Takaki, 2007).

The allelopathic compounds present in the extracts can affect the processes of respiration as in the case of the aqueous extracts of Ocotea odorifera (Vell.) Rohwer was able to reduce the cellular respiration of root Sorghum bicolor L. (Carmo, Borges, Takaki, 2007). In soybean seeds submitted to germination in aqueous extract of tiririca bulbs stimulation of the enzyme glucose-6phosphate dehydrogenase (6GPD) with an increase in the concentration of extracts. This enzyme is related with pentose phosphate oxidation and, according to the author, could accelerate the respiratory activity due to the presence of substances with such ability in the extract (Muniz et al., 2007).

In the photosynthesis of L. sativa, there was no significant difference between the control, but there was a strain in the inhibition concentrations of 250 and $500 \mu \mathrm{g} / \mathrm{mL}$, which ranged from 27 to $68 \%$ (Figure 4).

The reduction in the rate of photosynthesis can be explained by the closing of stomata, which decreases the absorption of $\mathrm{CO}_{2}$ by these organelles. In addition, the reduction of $\mathrm{Mg}$-porphyrin synthesis can be one of the reasons for the lower production of chlorophyll by $A$. 
A

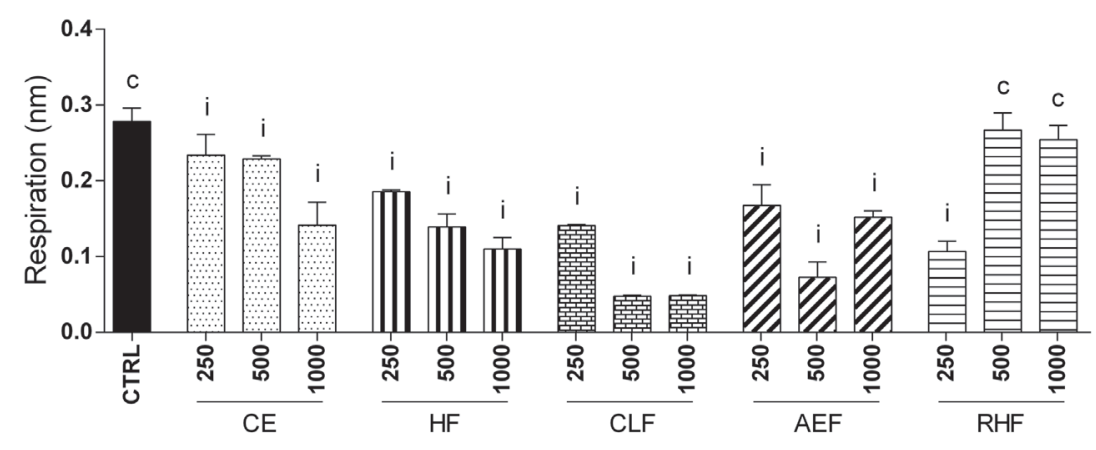

B

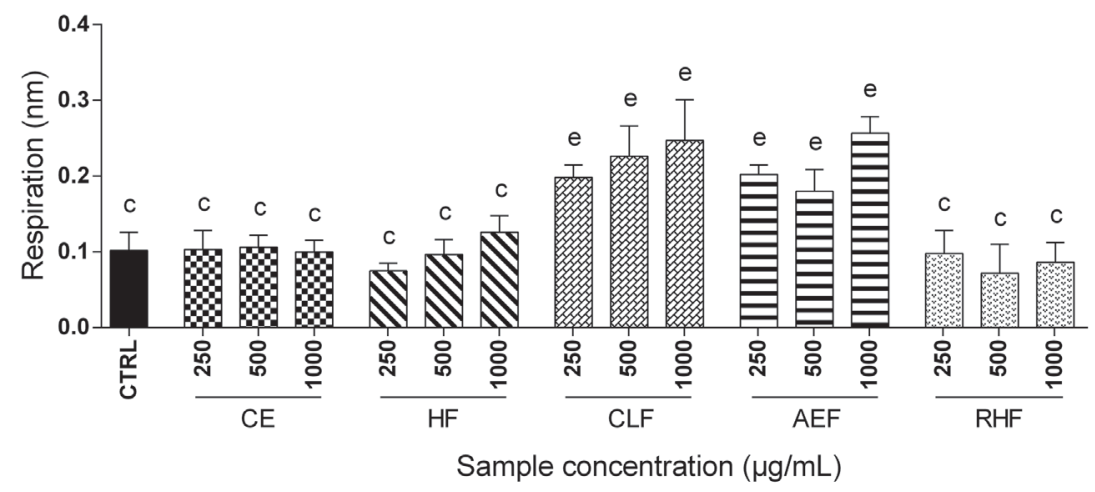

FIGURE 3 - Root respiration of L. sativa (A) and A. cepa (B). Treatment means differ significantly $(\mathrm{p}<0.05)$ when compared to control means inhibiting or ${ }^{\mathrm{e}}$ stimulating root respiration by Scott-Knott test. Treatment means do not differ significantly from ${ }^{\mathrm{c}}$ control means.

cepa, or the reduction of chlorophyll by the oxidation of the secondary compounds present in the crude extract and fractions may also be the reason (Einhellig, 1986).

The sorgoleone compound extracted from Sorghum bicolor inhibited photosynthesis in chloroplasts of pea and soybean leaves (Einhellig et al., 1993). In addition to inhibiting photosynthesis, the same metabolite has the ability to reduce oxygenation and cause leaf bleaching (Nimbal et al., 1996).

The photosynthesis of the P. ixocarpa leaves was evaluated with the $\beta$-caryophyllene compound isolated from $S$. salignus, and the samples treated with $100 \mu \mathrm{g} / \mathrm{mL}$ of the isolate, which produced effects on the photosynthesis of the target species in 72 hours of analysis. It was observed that the electron transport per cross section and the maximum quantum yield of primary photochemistry decreased by $50 \%$. In addition, the electron capture and transport decreased by about $50 \%$ (Sánchez-Muñoz et al., 2012).

Allelopathy is recognized as an important ecological process in natural and managed ecosystems, influencing the primary and secondary plant succession, structure, composition and dynamics of native or cultivated plant communities. In the latter case, the allelochemicals are seen as alternatives to synthetic agrochemicals, aiming at sustainable management and ecological agricultural production. Many allelopathic substances present great potential for use in the biological control of weeds. In contrast to power, the phytotoxic effects of germination and plant growth caused by allelochemicals are also of interest to agricultural management (Maraschin-Silva, Aqüila, 2006).

\section{CONCLUSION}

The species $S$. westermanii has phytotoxic activity on the species L. sativa and A. cepa, proven by the changes caused in the germination velocity index, growth, root respiration and photosynthesis. And for the seeds of L. sativa, the greatest influence was observed in radicle growth/root respiration and short embryonic inhibition in all the samples tested. As for A. серa, the biggest influences were observed in the growth of the radicle/coleoptile and photosynthesis, with inhibition 
A

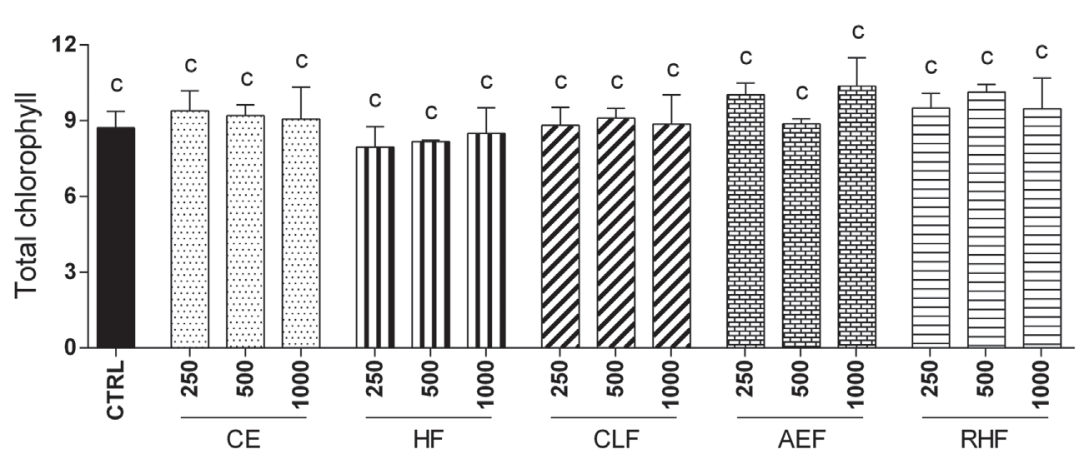

B

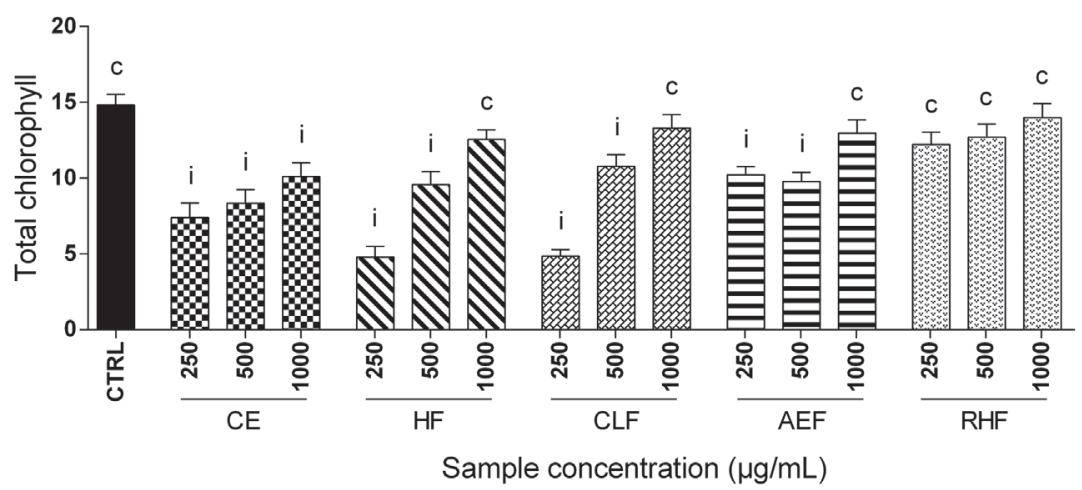

FIGURE 4 - Photosynthesis of L. sativa (A) and A. cepa (B). Treatment means differ significantly $(\mathrm{p}<0.05)$ when compared to control means inhibiting or ${ }^{\mathrm{e}}$ stimulating photosynthesis by Scott-Knott test. Treatment means do not differ significantly from ${ }^{c}$ control means.

in all the samples analyzed for root respiration, and there was an encouragement for the chloroform and ethyl acetate fractions. The identification of compounds present in the fractions is important to determine the components responsible for the side effects of inhibition and stimulation, thus making it essential for the isolation of these compounds in subsequent studies. In addition, the species $S$. westermanii is a potential species for use as a natural herbicide, decreasing the environmental impact caused by conventional herbicides.

\section{ACKNOWLEDGMENTS}

We would like to thank the CAPES and CNPq, for providing scholarships and funding the project, and the Municipal Botanical Museum of Curitiba City Hall, for the help in the identification of the species.

\section{DECLARATION OF INTEREST STATEMENT}

The author(s) have not declared any conflict of interests.

\section{REFERENCES}

Abdelgaleil S, Hashinaga F. Allelopathic potencital of two sesquiterpene lactones from Magnolia grandiflora L. Bioch Syst Ecol. 2007;35(11):737-742.

Ahmed M, Wardle DA. Allelopathic potential of vegetative and flowering ragwort (Senecio jacobaea L.) plants against associated pasture species. Plant Soil. 1994;16491:61-68.

Arnon DI. Copper enzimes in isolated chloroplasts. Polyphenoloxidase in Beta vulgaris. Plant Physiol. 1949;24(1):115.

Barnes JP, Putnan AR, Burke BA, Aasen AJ. Isolation and characterization of allelochemicals in rye herbage. Phytochemistry. 1987;26(5):1385-1390.

Belinelo VJ, Czepak MP, Filho SAV, Menezes LFT, Jamal CM. Alelopatia de Arctium minus Bernh (Asteraceae) na germinação e crescimento radicular de sorgo e pepino. Rev Caatinga. 2008;21(4):12-16. 
Borella J, Pastorini LH. Interferência alelopática de extratos aquosos de raízes de erva-moura (Solanum americanum) sobre a germinação e o crescimento inicial do rabanete. Tecn Ciên Agropec. 2009;3(2):31-36.

Brasil. Ministério da Agricultura, Pecuária e Abastecimento. Regras para análise de sementes. Brasília: Mapa/ACS; 2009. p.398.

Burgueño-Tapia E, González-Coloma A, Martín-Benito D, Joseph-Nathan P. Antifeedant and phytotoxic activity of cacalolides and eremophilanolides. Verlag Z Naturforsch. 2007;62(5-6):362-366.

Cândido ACS, Schmidt V, Laura VA, Faccenda O, Hess SC, Simionatto E, et al. Potencial alelopático da parte aérea de Senna occidentalis (L.) Link (Fabaceae, Caesalpinioideae): bioensaios em laboratório. Acta Bot Brasil. 2010;24(1):235-242.

Carvalho JLS, Cunico MM, Dias JFG, Miguel MD, Miguel OG. Termoestabilidade de processos extrativos de Nasturtium officinale R. Br., Brassicaceae por sistema Soxhlet modificado. Quím Nova. 2009;32(4):1031-1035.

Carmo FMS, Borges EEL, Takaki M. Alelopatia de extratos aquosos de canela-sassafrás (Ocotea odorifera (Vell.) Rohwer). Acta Bot Brasil. 2007;21(3):697-705.

Cruz-Silva CTA, Nasu EGC, Pacheco FP, Nobrega LHP. Allelopathy of Bidens sulphurea L. aqueous extracts on lettuce development. Rev Brasil Plan Medic. 2015;17(4):679-684.

Cruz-Silva CTA, Satorum M, Bini FV. Efeito alelopático de extratos aquosos de Senecio brasiliensis (Spreng) Less sobre a germinação e o desenvolvimento de plântulas. Cult Sab. 2009;2(1):62-70.

Dodd GL, Donovan LA. Water potential and ionic effects on germination and seedling growth of two cold desert shrubs. Am J Bot. 1999;86(8):1146-1153.

Einhellig FA, Rasmussen JA, Hejl AM, Souza IF. Effects of root exudate sorgoleone on photosynthesis. J Chem Ecol. $1993 ; 19(2): 369-375$.

Einhellig FA. Mechanisms and modes of action of allelochemicals. In: Putnam AR, Tang CS (editors.). The Science of Allelopathy. New York: John Wiley and Sons; 1986. p.171-188.
El-Amier YA, Abdullah TJ. Allelopathic effect of four wild species on germination and seedling growth of Echinocloa crus-galli (L.) P. Beauv. Inter J Advan Res. 2014;2(9):287-294.

Ferreira MC, Souza JRP, Faria TJ. Allelopathy of plant extracts on germination and initial growth of beggartick (Bidens pilosa L.) and lettuce (Lactuca sativa L.). Ciên Agrotec. 2007;31(4):1054-1060.

Francescato LN, Deuschle RAN, Mallmann CA, Alves SH, Heinzmann BM. Atividade antimicrobiana de Senecio heterotrichius DC. (Asteraceae). Rev Brasil Ciên Farm. 2007;43(2):239-245.

Gatti AB, Perez SCJGA, Lima MIS. Atividade alelopática de extratos aquosos de Aristolochia esperanzae O. Kuntze na germinação e no crescimento de Lactuca sativa L. e Raphanus sativus L. Acta Bot Brasil. 2004;18(3):459-472.

Hoffmann CEF, Neves LAS, Bastos CF, Wallau GL. Atividade alelopática de Nerium oleander L. e Dieffenbachia picta Schott em sementes de Lactuca sativa L. e Bidens pilosa L. Rev Ciên Agrov. 2007;6(1):11-21.

Krause MS, Duarte AFS, Merino FJZ, Paula CS, Miguel MD, Miguel OG. Phytotoxic Analysis of Extract of Leaves of Solanum megalochiton Mart. Solanaceae on Lactuca sativa L. and Allium cepa L. Int J Scien. 2016;5:36-42.

Laboriau LG. A germinação das sementes. Washington: Secretaria Geral da Organização dos Estados Americanos; 1983. p. 170 .

Lichtenthaler HK. Chlorophylls and carotenoids: pigment of photosynthetic biomembranes, in: Colowick SP, Kaplan NO (editors). Methods in enzymology. New York: Academic Press; 1987. p.350-382.

Lima CP, Cunico MM, Miguel OG, Miguel MD. Efeito dos extratos de duas plantas medicinais do gênero Bidens sobre o crescimento de plântulas de Lactuca sativa L. Rev Ciên Farmac Bás Aplic. 2011;32(1):83-87.

Macias FA, Castellano D, Molinillo JMG. Search for a standart phytotoxic bioassay for allelochemicals. Selection of standard target species. J Agric Food Chem. 2000;48(6):2512-2521.

Maraschin-Silva F, Aquila MEA. Potencial alelopático de espécies nativas na germinação e crescimento inicial de Lactuca sativa L. (Asteraceae). Acta Bot Brasil. 2006;20(1):61-69. 
Merino FJZ, Oliveira VB, Paula CS, Cansian FC, Souza AM, Zuchetto $\mathrm{M}$, et al. Análise fitoquímica, potencial antioxidante e toxicidade do extrato bruto etanólico e das frações da espécie Senecio westermanii Dusén frente à Artemia salina. Rev Bras Plan Medic. 2015;17(4):1031-1040.

Moreira PFSD, Souza DR, Terrones MGH. Avaliação do potencial alelopático do extrato metanólico obtido das folhas de Caryocar brasiliense Camb. (pequi) na inibição do desenvolvimento da raiz em sementes de Panicum maximum. Biosc J. 2008;24(3):74-79.

Możdżeń K, Repka P. Allelopathic influence of aqueous extracts from the leaves of Morus alba L. on seed germination and seedling growth of Cucumis sativus L. and Sinapsis alba L. Mod Phytom. 2014;5:93-99.

Muniz FR, Cardoso MG, Pinho EVRV, Vilela M. Qualidade fisiológica de sementes de milho, feijão, soja e alface na presença de extrato de tiririca. Rev Bras Semen. 2007;29(2):195-204.

Netzly DH, Riopel JL, Ejeta G, Butler LG. Germination stimulants of witchweed (Striga asiatica) from hydrophobic root exudate of sorghum (Sorghum bicolor). Weed Scien. 1988;36(4):441-446.

Nimbal CI, Yerkes CN, Weston LA, Weller SC. Phytotoxicity and distribution of sorgoleone in grain sorghum germ plasm. J Agric Food Chem. 1996;44(5):1343-1347.

Oliveira SCC, Gualtieri SCJ, Dominguez FAM, Molinillo JMG, Montoya RV. Estudo fitoquímico de folhas de Solanum lycocarpum A. St.-Hil (Solanaceae) e sua aplicação na alelopatia. Acta Bot Brasil. 2012; 26(3):607-618.

Parvez S, Parvez M, Fujii Y, Gemma H. Differential allelopathic expression of bark and seed of Tamarindus indica L. Plant Grow Reg. 2004;42(3):245-252.

Portero AG, González-Coloma A, Reina M, Díaz CE. Plant-defensive sesquiterpenoids from Senecio species with biopesticide potential. Phytochem Rev. 2012;11(4):391-403.

Reina M, Nold M, Santana O, Orihuela JC, González-Coloma A. C-5-substituted antifeedant silphinene sesquiterpenes from Senecio palmensis. J Nat Prod. 2002;65(4):448-453.
Reina M, Santana O, Domínguez DM, Villarroel L, Fajardo V, Rodríguez ML, González-Coloma A. Defensive sesquiterpenes from Senecio candidans and S. magellanicus, and their structureactivity relationships. Chem Biodivers. 2012;9(3):625-643.

Rivero-Cruz I, Trejo JL, Aguilar MI, Bye R, Mata R. Phytotoxic coumpounds from Xanthocephalum gymnospermoides var. eradiatum. Planta Medica. 2000;66(8):734-739.

Sánchez-Muñoz BA, Aguilar MI, King-Díaz B, Rivero JF, Lotina-Hennsen B. The sesquiterpenes $\beta$-caryophyllene and caryophyllene oxide isolated from Senecio salignus act as phytogrowth and photosynthesis inhibitors. Molecules. 2012;17(2):1437-1447.

Schutt P, Schuck HJ, Sydow AV, Hatzelmann H. Allelopathic effects of forest weeds. I. Infiuence of weed extracts on the development of rool hairs of Picea abies seedlings. Forstwissen Centrat. 1975;94:43-53.

Silva PSS. Atuação dos aleloquímicos no organismo vegetal e formas de utilização da alelopatia na agronomia. Biotemas. 2012;25(3):65-74.

Souza LS, Velini ED, Maiomoni-Rodella RCS. Efeito alelopático de plantas daninhas e concentrações de capimbraquiária (Brachiaria decumbens) no desenvolvimento inicial de eucalipto (Eucalyptus grandis). Planta Daninha. 2003;21(3):343-354.

Souza Filho APS, Guilhon GMSP, Santos LS. Metodologias empregadas em estudos de avaliação da atividade alelopática em condições de laboratório - revisão crítica. Planta Daninha. 2010;28(3):689-697.

Steponkus PL, Lanphear FO. Refinement of the triphenyl tetrazolium chloride method of determining cold injury. J Plant Phys. 1967;42(10):1423-1426.

Wandscheer ACD, Pastorini LH. Interferência alelopática de Raphanus raphanistrum L. sobre a germinação de Lactuca sativa L. e Solanum lycopersicon L. Ciênc Rural. 2008;38(4):949-953.

Received for publication on $21^{\text {st }}$ March 2017 Accepted for publication on $23^{\text {th }}$ January 2018 